\title{
$S-O-V-X$ Constituent Order and Constituent Order Alternations in West African Languages
}

\author{
DENIS CREISSELS
}

University of Lyon

\section{Introductory remarks.}

In current presentations of constituent order typology, the notion of $S-O-V$ constituent order is implicitely treated as more or less equivalent to the notion of verb final language. The reason for this confusion is that, in most languages, objects and obliques occupy the same position in relation to the verb, and differ only in a tendency of objects to stand closer to the verb, so that $S-V-O, S-O-V$, $V-S-O$ and $V-O-S$ can generally be considered equivalent to $S-V-O-X, S-X-O-V$, $V$-S-O-X and $V$ - $O-X-S(\mathrm{X}=$ oblique). This however does not hold for languages in which core syntactic terms ( $\mathrm{S}$ and $\mathrm{O}$ ) precede the verb, and all obliques follow it ( $S$ - $O-V-X$ constituent order), as in Bambara -ex. (1), or in Soninke -ex. (2).

(1) Bambara
a. sékù bé mădù kálán tùbàbùkán `ná
Sékou PM Madou teach French Po
'Sékou is teaching French to Madou'

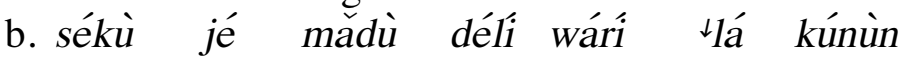
Sékou PM Madou ask money Po yesterday
'Sékou asked Madou for money yesterday'
c. sékù jé mǎdù nèní à mùsó ınéná sìné fìlà
Sékou PM Madou teach 3S wife Po time two
'Sékou insulted Madou twice in the presence of his wife'
d. ̀̀ bénà fántà di à mà mùsó \yé
3P PM Fanta give 3S Po wife Po
'They will give him Fanta as a wife'

(2) Soninke
a. fààú dà
dà tijè-n qóbó
sáxà-n
ná
Fatou PM meat-DEF buy market-DEF Po
'Fatou has bought meat at the market' 
b. fààtú dà tijjè-n yígándi lémínè-n gá Fatou PM meat-DEF eat-CAUS child-DEF Po 'Fatou had the child eat meat'

b. ó dà qáálisí ké kínì à yí

1P PM money DEM give $3 \mathrm{~S}$ Po

'We gave him/her the (aforementioned) money'

It has often been claimed that the $S-O-V-X$ type of constituent order is one of the morphosyntactic features that concern a proportion of African languages significantly higher than that observed at world level, and that within the limits of the African continent, this type of constituent order pattern shows a particular concentration in West Africa, where in addition to the whole Mande family it is found also, at least to some extent, in languages belonging to the Kwa, Gur, Kru, Songhay, and Atlantic families.

This is certainly not entirely false, in the sense that the canonical variety of the $S-O-V$ pattern (with the verb in clause-final position) is particularly rare in West Africa, where its only representatives are Dogon and Ijo, whereas constituent order patterns that do not fit the current $S$ - $V$ - $O$ vs. $S$ - $O$ - $V$ distinction are common in West Africa. But the West African languages whose constituent order patterns cannot be straightforwardly identified as belonging to the $S-V-O$ or to the $S-O-V$ type show in some important respects a variety that may cast some doubt on Heine's claim that all these languages can be groupped into a single type (his 'type B'), and on more recent claims that, taken as a whole, they provide converging evidence supporting the reconstruction of a constituent order of the Mande type in Proto-Niger-Congo.

The point is that most authors seem to take for granted that the $S-O-V-X$ pattern found in the languages of the Mande family and in a few other languages that share with Mande the absence of constituent order alternations is also found as the alternative to $S-V-O-X$ in the West African languages that have $V-O \sim O-V$ alternations. What I would like to show is that things are not so simple, and that in the languages that have $V-O \sim O-V$ alternations, the variant characterized by the anteposition of the object to the verb differs in some important respects from the $S-O-V-X$ constituent order that constitutes the only possible constituent order in Mande languages. In other words, what I would like to show is that West African languages with $V-O \sim O-V$ alternations cannot be straightforwardly characterized as having an alternation between a canonical $S-V-O(-X)$ constituent order and a $S-O-V-X$ constituent order of the Mande type. An important conclusion will be that data from West African languages with $V-O \sim O-V$ alternations should be used with extreme caution in attempts at reconstructing Proto-Niger-Congo constituent order. 


\section{The $S-O-V-X$ constituent order in Mande languages}

\subsection{Rigidity of the $S-O-V-X$ constituent order}

In Mande languages, the $S-O-V-X$ constituent order is absolutely rigid in the sense that it is neither restricted to particular types of clauses, nor conditioned by certain characteristics of the object NP. Moreover, Mande languages are extreme 'configurational' languages, in which changes in the position of the NP representing a given participant always imply other changes in the construction. In cases when the same participant can optionally be represented by a term inserted between $S$ and $V$, or by a term following $V$, the second construction implies the use of adpositions. Consequently, the change in constituent order is not the result of a mere possibility of choice within the frame of the same construction, and must be analyzed as the consequence of a valency alternation of the antipassive type (demotion of the second argument of transitive verbs to the status of oblique), as illustrated by ex. (3).

(3) Bambara

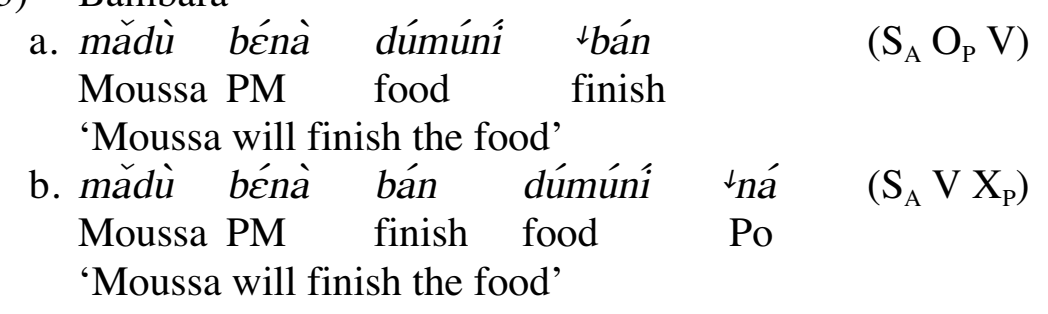

\subsection{Never more than one nominal term inserted between $S$ and $V$}

In Mande languages, the patient of typical transitive verbs regularly occurs inserted between the subject and the verb, i.e., in the syntactic role of object, but Mande languages do not have constructions in which a second nominal term would be inserted between the subject and the verb, either as a second object in a double object construction, or in an oblique role.

This means in particular that, in the construction of verbs of giving, which cross-linguistically are the most typical ditransitive verbs, one participant only (either the thing given, or the recipient) can be encoded as an object, and the only possibility for the third participant is to appear as an oblique, as illustrated by ex. (4) to (6).

(4) Bambara
a. sékù jé wárí ๖dí mădù mà Sékou PM money give Madou Po 'Sékou gave money to Madu'

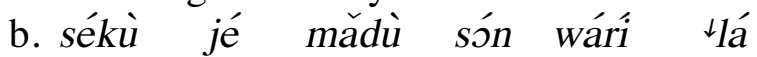 Sékou PM Madou give money Po

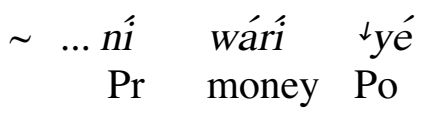
Pr money Po 'Sékou gave money to Madou' 
(5) Soso
a. ń ningéé fíi-mà í má
1S cow give-TAM $2 \mathrm{~S}$ Po
'I will give you a cow'
b. $n$ í kíi-mà nìngéé rá
1S 2S give-TAM cow Po
'I will give you a cow'

(6) Mende (Innes 1971)
a. mbeí ve kpaná we
rice give Kpana Po
'Give the rice to Kpana'
b. kpanâ gó a mbeí
Kpana give $\mathrm{Pr}$ rice
'Give the rice to Kpana'

The only apparent exceptions to the ban on the insertion of more than one nominal term between $S$ and $V$ are instances of incorporation, as in ex. (7). Note that, in Bambara, incorporation is made apparent by the tonal contour of the sequence incorporated noun + verb.

(7) Bambara
a. dókótóró ‘má fántà fúrá-ké
doctor PM Fanta medecine-do
'The doctor did not attend Fanta'
b. ù yé cèkòròbá wùlù-fáá
3P PM old man dog-kill
'They killed the old man like a dog'

\subsection{Predicative markers and verbal inflection}

Most Mande languages have a very reduced verbal inflection and make a wide use of auxiliaries (called predicative markers in many descriptions of Mande languages) that obligatorily follow the subject. For example, as illustrated by ex. (8), Bambara, like the majority of Central Mande languages, marks tense, aspect, and mood by predicative markers following the subject and expressing also the positive vs. negative distinction. The only exceptions are the imperative singular positive, which has no mark at all, and the intransitive past/perfective positive, marked by a verbal suffix.

(8) Bambara
a. woman PM
mùsó ${ }^{\downarrow} b \varepsilon$
mùsó $\downarrow$ té
mùsó \táá-rá
go,
táá
táá
'The woman is going'
'The woman is not going'
'The woman went / has gone' 


\begin{tabular}{|c|c|c|c|c|}
\hline mùsó & $\iota^{\downarrow} \mathrm{má}$ & \multicolumn{2}{|l|}{ táá } & $\begin{array}{l}\text { 'The woman did not go } \\
\text { / has not gone' }\end{array}$ \\
\hline mùsó & ${ }^{\downarrow}$ bénà $\sim \downarrow_{\text {ná }}$ & \multicolumn{2}{|l|}{ táá } & 'The woman will go' \\
\hline mùsó & ¿ténà & \multicolumn{2}{|l|}{ táá } & 'The woman will not go' \\
\hline mùsó & ${ }^{\downarrow} k a ́$ & \multicolumn{2}{|l|}{ táá } & 'The woman should go' \\
\hline mùsó & kàná & \multicolumn{2}{|l|}{ ¿táá } & 'The woman should not go' \\
\hline \multicolumn{4}{|l|}{ táá } & 'Go!' \\
\hline \multicolumn{4}{|c|}{ kàná ‘táá } & 'Don't go!' \\
\hline \multicolumn{5}{|c|}{ woman $\mathrm{P}$} \\
\hline mùsó & ${ }^{\downarrow} b \varepsilon^{\prime}$ & jégé & sàn & 'The woman is buying fish' \\
\hline mùsó & 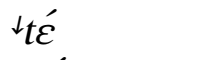 & jégé & sàn & 'The woman is not buying fish' \\
\hline mùsó & ${ }^{\downarrow}$ yé & jégé & sàn & $\begin{array}{l}\text { 'The woman bought } \\
\text { / has bought fish' }\end{array}$ \\
\hline mùsó & ${ }^{\downarrow}$ má & jégé & sàn & $\begin{array}{l}\text { 'The woman did not buy } \\
\text { / has not bought fish' }\end{array}$ \\
\hline mùsó & ${ }^{\downarrow}$ bénà $~ \downarrow^{\downarrow}$ á & jégé & sàn & 'The woman will buy fish' \\
\hline mùsó & ${ }^{\downarrow}$ ténà & jégé & sàn & 'The woman will not buy fish' \\
\hline mùsó & ${ }^{\downarrow} k a ́$ & jéǵ & sàn & 'The woman should buy fish' \\
\hline mùsó & kàná & 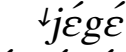 & sàn & 'The woman should not buy fish' \\
\hline jégé sàn & & yé je & & 'Buy fish!' \\
\hline kàná $\downarrow j \varepsilon$ & gé sàr & kàná & Ćgé sàn & 'Don't buy fish!' \\
\hline
\end{tabular}

The situation of Mande languages is however far from uniform in this respect. On the one hand, Koyaga, a manding dialect spoken in Ivory Coast, differs from Bambara by using a predicative marker in the intrantive past/perfective positive too, and therefore has no verbal inflection at all. But on the other hand, several Mande languages (for example, Soso) have a relatively developped verbal inflection, and mark several TAM values without making use of predicative markers.

An important characteristic of the Mande systems of predicative markers is that most of them cannot be analyzed as auxiliary verbs. Moreover, for some of them, there is evidence that they developped from other categories than verbs, in particular, from postpositions (see Bird and Kendall 1986, Bearth 1995, Creissels 1997a, Kastenholtz 2003).

It is therefore not entirely correct to characterize Mande constituent order as $S$ $A u x-O-V-X$, as often proposed. An accurate representation of the Mande pattern not limited to the lexical verb and the nominal terms of its construction should rather be something like $S$-neg(tam)-O-V(tam)-X.

\subsection{No evidence of a different pattern of constituent order in Proto-Mande}

Claudi 1994 claims that, originally, Mande languages had the $S-V-O-X$ order at clause level, but the order $G-N$ (genitival dependent + head noun) in the noun phrase, and that the $S-O-V-X$ order is an innovation resulting from the reanalysis of constructions of the type auxiliary + nominalized verb, in which the NP that 


\section{Denis Creissels}

would have constituted the object of a finite form of the nominalized verb was treated as a genitival dependent. This is undoubtedly a possible scenario, which considerably weakens previous claims according to which Mande constituent order provides evidence that the constituent order of Proto-Niger-Congo was $S-O-V$. However, Claudi's proposal is entirely speculative, since

(a) in Mande languages, the uniformity of word order and constituent order patterns is total, and therefore cannot provide the slightest evidence of the previous existence of a constituent order other than $S-O-V-X$, and

(b) the auxiliarization processes postulated by Claudi can also operate within the frame of a constituent pattern identical with that of present-day Mande languages without inducing any change in the linearization rules.

Morover, other equally plausible grammaticalization processes can lead to the same shift from $S$ - $V-O-X$ to $S-O-V-X$, for example the replacement of a transitive construction conforming to the pattern $S-V-O-X$ by a serial verb construction $S$ take $O V X$, followed by the decategorialization of take, a process widely attested for example among Kwa languages. ${ }^{1}$

In other words, internal evidence from Mande languages leaves us with the default hypothesis that Proto-Mande had word order patterns identical to those attested in the modern Mande languages. To what extent this can be considered as an argument for reconstructing $S-O-V-X$ at Proto-Niger-Congo level, as suggested in several recent studies, ${ }^{2}$ is another question, to which we will return after examining the constituent patterns of other West African languages currently viewed as having a constituent order pattern of the Mande type in at least certain conditions.

\section{Non-Mande languages with a rigid $S-O-V-X$ constituent order}

Non-Mande languages with exactly the same pattern of constituent order as Mande are not very numerous. This situation seems to be restricted to languages spoken in areas they share with Mande languages. Senufo languages constitute the best known case. Carlson 1994 provides a detailed and precise description of the morphosyntax of a Senufo language, which shows that this language shares with Mande, not only the absolute rigidity of the $S-O-V-X$ constituent order, but also the impossibility to insert more than one nominal term between $S$ and $V$. As in Mande, even the most typical ditransitive verbs cannot be constructed with two nominal terms inserted between $\mathrm{S}$ and $\mathrm{V}-\mathrm{ex}$. (9a-b), and whenever the second

\footnotetext{
${ }^{1}$ See Lord 1993. Given the universal affinity between the syntactic notions of subject and object and the discursive notions of topic and focus, another possible scenario is the syntacticization of a pragmatically driven constituent order $T-F-V$-others $(\mathrm{T}=$ topic, $\mathrm{F}=$ focus $)$ of the type attested for example in Basque or in Hungarian. An additional argument against Claudi's hypothesis is that, if the emergence of the $S-O-V-X$ constituent order could be the mere consequence of auxiliarization in $S$ - $V$ - $O$ - $X$ languages in which the genitival dependent precedes its head, the Mande pattern should be common elsewhere in the world, since $S$ - $V$ - $O-X$ languages anteposing the genitival dependent are not rare, and auxiliarization processes are universal.

${ }^{2}$ See Gensler 1994, Gensler 1997, Gensler \& Güldemann 2003.
} 
argument of a transitive verb can be represented by a nominal term in postverbal position, the presence of a postposition indicates that this is an instance of a valency alternation of the antipassive type, whereby the object has been demoted to oblique - ex. $(9 \mathrm{c}-\mathrm{d}) .^{3}$

(9) Supyire (Carlson 1994, Carlson 2000)
a. mìi a sém-píi cyèè alí na
1S PM papers-DEF show Ali Po
'I have shown the papers to Ali'
b. mìi a ù kàn nùjìrimè na
1S PM 3S give milk Po
'I have given him/her milk'
c. $u$ a mipàa-bíi bò $\left(\mathrm{S}_{\mathrm{A}} \mathrm{O}_{\mathrm{P}} \mathrm{V}\right)$
3S PM sheep.PL-DEF kill
'He/she has killed the sheep (PL)'
d. $u$ a bo ìpàa-bíl-ê $\left(\mathrm{S}_{\mathrm{A}} \mathrm{V} \mathrm{X}_{\mathrm{P}}\right)$
3S PM kill sheep.PL-DEF-Po
'He/she has killed some of the sheep'

\section{The constituent order pattern of Eastern Songhay}

In Eastern Songhay, illustrated here by Zarma and Gao Songhay, ${ }^{4}$ the $S-V-O-X$ constituent order (which is the only possible constituent order in Western Songhay and in Northern Songhay) has a marginal status. For typical transitive verbs, the $S-O-V-X$ order is, either the only possible order (in Gao Songhay), or the preferred order (in Zarma). As in Mande, in clauses with a constituent order of the $S-O-V$ - $X$ type, no more than one nominal term can be inserted between $S$ and $V$, as illustrated by ex. (10).

(10) Zarma (Oumarou Yaro 1993)
a. ábdù nà fèèji wîi yàwòó sè Abdou PM sheep kill guest.DEF Po
'Abdou has killed a sheep for the guest'
b. múúsà nà ńgà moótàà nóó káynòó sè Moussa PM 3S car.DEF give younger brother.DEF Po
'Moussa has given his car to his younger brother'

Apart from the fact that the $S-O-V-X$ pattern of Eastern Songhay is virtually identical with that of Mande, a particularity that sharply distinguishes Eastern Songhay from Mande is the existence of a limited class of semantically bivalent verbs whose second argument must occur in postverbal position, but shows no

\footnotetext{
3 As discussed in Carlson 2000, the possible meanings of the antipassive construction of Supyire are 'partially affected undergoer' (as in the example reproduced here) and 'participatory agent'.

${ }^{4}$ On Zarma, see Oumarou Yaro 1993. On Gao Songhay, see Heath 1999.
} 
evidence of an oblique status, as illustrated by ex. (11). Oumarou Yaro argues that the behavioral properties of the second argument of such verbs do not differ from those of the second argument or prototypical transitive verbs, and that consequently this constituent must be recognized as a variety of object. ${ }^{5}$ The same analysis is proposed by Heath for Gao Songhay.

(11) Zarma (Oumarou Yaro 1993)
a. ábdù gá hìmá bààbò Abdou PM resembles father.DEF
'Abdou resembles his father'
b. ábdù gà báá hăysà / *ábdù gá hăysà bâ
Abdou PM love Aïssa
'Abdou loves Aïssa'
c. ábdù dii zànkày / *ábdù nà zànkày dí Abdou see child.PL.DEF
'Abdou saw the children'

Moreover, in Zarma (but apparently not in Gao Songhay), the $S-O-V-X$ constituent order is not the only possible constituent order in clauses headed by a prototypical transitive verb. In Zarma, with prototypical transitive verbs, the $S$ - $V$ $O-X$ order is not frequent, but it is possible, and without any apparent conditioning, as illustrated by ex. (12).

(12) Zarma (Oumarou Yaro 1993)
a. à nà gòryòò wî̀ yàwòó sè
3S PM chicken.DEF kill guest.DEF Po
'He is going to kill the chicken for the guest'
$3 \mathrm{~S}$ kill chicken.DEF guest.DEF Po
'He is going to kill the chicken for the guest'
b. à wîi gòryooó yàwòó sè 6

In Zarma, contrary to Mande or Senufo, this variation between two possible positions of a term representing the second argument or prototypical transitive verbs seems to be nothing more than a free variation in the linearization of the transitive construction, since no postposition marks the second argument of prototypical transitive verbs in postverbal position, and more generally, there seems to be no evidence that this variation should be analyzed as the result of a

\footnotetext{
5 Oumarou Yaro 1993 gives the following list of transitive verbs whose object cannot occur in preverbal position: máá 'hear', 'feel', dî 'see', dòoná 'be accostumed to', dùù 'get', 'have', hín 'surpass', hìmá 'resemble', màànù 'approach', báà 'like', wáání 'know'.

${ }^{6}$ Note that, in Zarma, the predicative marker of the perfective positive occurs only in the $S O V X$ construction, not when the verb immediately follows the subject. The other predicative markers are not sensitive to this distinction.
} 
construction change of the antipassive type. Oumarou Yaro explicitely states that nothing in his observations or in his native speaker intuitions suggests any explanation of this variation.

Heath signals an interesting particularity of the constituent order pattern of Gao Songhay which is related to the existence of postverbal objects, and therefore has no equivalent in Mande syntax. As already indicated, Eastern Songhay, like Mande, forbids the insertion of two non-conjoined NPs between the subject and the verb. But the existence of a second position for objects (to the right of the verb) results in the possibility of double object constructions in which one of the two objects follows the verb, and this is precisely what happens with the verb noo 'give'. In Gao Songhay, this verb has two possible constructions: either the thing given is encoded as a preverbal object, and the recipient as an oblique, as in ex. (13a), or the recipient is encoded as a preverbal object, and the thing given as a postverbal object, as in ex. (13b).

(13) Gao Songhay (Heath 1999)

a. a na atteyoo noo yane
3S PM tea.DEF give 1S.DAT
'She gave me the tea'
b. a na ey noo atteyoo
3S kill 1S give tea
'She gave the tea to me'

\section{Other types of constituent order alternations}

\subsection{General remarks}

We now turn to the case of West African languages which share with Zarma the existence of alternations in the constituent order involving $S-V-O-X$ as one of the two alternative orders, but in which the pattern that alternates with $S-V-O-X$ is not entirely identical with (and sometimes very different from) the $S-O-V-X$ pattern of Mande. Such alternations are a widespread phenomenon in the Gur, Kwa, and Kru families, and are attested in some Atlantic languages too. I will argue in section 6 that recent studies tend to overestimate their frequency. But before examining this question, what I would like to show first is that, in contrast with the situation found in West African languages that invariably put the object in preverbal position, the constituent order patterns of the languages examined in this section are not uniform. They have in common that the variation (in contrast with the situation observed in Eastern Songhay) is conditioned by TAM or polarity: the use of a constituent pattern other than $S-V-O-X$ is commonly restricted to clause types characterized by the presence of overt predicative markers immediately after the subject. But the details of the conditioning greatly differ from one language to another, and no generalization is possible concerning the TAM and polarity values that trigger a constituent order other than $S-V-O-X$. There are also important differences in the range of nominal terms involved in the alternation, with the result that treating them indistinctly as intances of a variation 
between the canonical $S$ - $V$ - $O$ pattern and the Mande pattern implies some dose of oversimplification.

The three cases examined below are not intended to give a comprehensive view of the question, but only to illustrate the heterogeneity of the constituent order patterns found among West African languages, and to emphasize the necessity to gather more detailed and more precise information on this matter before any serious attempt to establish a detailed typology of the constituent order patterns found in West Africa.

\subsection{Kisi}

Kisi, ${ }^{7}$ an Atlantic language spoken in Sierra Leone and Guinea, illustrates an alternation in constituent order triggered by the presence of an auxiliary immediately after the subject, in which the pattern alternating with $S-V-O-X$ differs from the Mande type in that more than one constituent may be involved in the alternation.

Contrary to Mande languages, Kisi has multiple object constructions in which two or even three ${ }^{8}$ nominal terms in the syntactic role of object take part in the alternation, as in ex. (14).

(14) Kisi (Childs 2003)

a. ò ké yá tòòlúlán

$3 \mathrm{~S}$ give $1 \mathrm{~S}$ support

'She gave me support'

b. à wá ndú kooówán kiooo

3P PM 3S medecine give

'They were giving him medecine'

Moreover, in Kisi, the alternation is not strictly limited to objects. Most obliques invariably remain in postverbal position, but at least some of them can occur between the predicative marker and the verb in the same conditions as objects, in particular time adverbs. In ex. (15), two objects and one oblique are inserted between the predicative marker and the verb.

(15) Kisi (Childs 2003)

ò cò nî̀ yá mààlón hùngùlló

$3 \mathrm{~S}$ PM now $1 \mathrm{~S}$ rice beat.APPL

'He is beating the rice for me now'

\footnotetext{
${ }^{7}$ Childs 1995.

${ }^{8}$ In Kisi, constructions with three objects are possible with the applicative form of ditransitive verbs.
} 
The differences with the Mande pattern are striking, more especially as Kisi is surrounded by Mande languages and is considered to have been influenced by Mande languages: the fact that Kisi puts in preverbal position terms that Mande languages would put in postverbal position is difficult to reconcile with the hypothesis of a development under Mande influence. Since Kisi, like other Atlantic languages, has the order $N-G$ in noun phrases, Claudi's reanalysis scenario is not available either as the explanation of a possible independent shift from $S-V-O-X$ to the pattern attested in clauses including an auxiliary.

\subsection{Attie}

Attie, ${ }^{9}$ a Kwa language spoken in Ivory coast, attests a situation in which the range of terms involved in the constituent order alternation includes not only the two objects of fairly typical double object constructions, but also locative terms whose status as objects or adjuncts is not entirely clear. For example, in sentence (16a), the two objects precede the verb, but the locative term 'at the market' follows it. By contrast, in sentence (16b), the locative term 'in the forest' precedes the verb. The solution proposed by Kouadio is that in Attie, oblique arguments take part in the alternation in the same way as objects, whereas adjuncts invariably remain in postverbal position. A more detailed description of Attie syntax would however be necessary in order to evaluate this hypothesis.

(16) Attie (Kouadio 1996)
a. $m \overline{\tilde{\varepsilon}}$ ji-īi jàpí jìkā dzé jábò $1 \bar{\emptyset}$
1S father-PM Yapi money give market there
'My father is giving money to Yapi at the market'

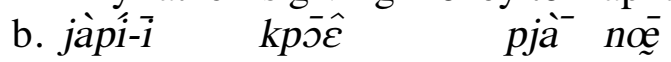
Yapi-PM forest.DEF in walk
'Yapi is walking in the forest'

\subsection{Neyo}

$\mathrm{Neyo}^{10}$ is an Eastern Kru language spoken in Ivory Coast.

Alternations between $S$ - $V-O-X$ and a constituent order in which the object precedes the verb are general in Kru languages, and they are conditioned by the presence of an auxiliary inserted immediately after the subject. It is also general in Kru languages that, much in the same way as in Kisi or in Attie, and in contrast to the situation observed in Mande, the alternation may involve more than one nominal term, and is not restricted to objects. The available data suggests that, at least in some Eastern Kru languages, the alternative constituent pattern can be characterized as $\mathrm{S}-\mathrm{O}-\mathrm{X}-\mathrm{V}$, i.e. as verb-final, but with an interesting particularity: in most verb-final languages, the default position of the object is immediately before the verb. By contrast, in Eastern Kru languages, the final position of the

\footnotetext{
${ }^{9}$ Kouadio 1996.

10 Grah 1983.
} 
verb does not seem to affect the relative order $O-X$. In her description of Neyo, Grah explicitely states that $S-O-X-V$ is the canonical constituent order triggered by a set of 6 predicative markers. She however adds that the relative ordering of objects and obliques is not rigid, and that in verb-final clauses, obliques may precede the object, or even occur in postverbal position -ex. (17).

(17) Neyo (Grah 1983)
a. kóní ní sáká jàlé Ii
Koni PM rice kitchen eat
'Koni has not eaten rice in the kitchen'
b. làlı́ yá mágìtí kú liéplù yé
Lali PM market Po scarf see
'Lali has seen a scarf at the market'
b. kóní níkā nú mlā zímlē
Koni PM water drink today
'Koni will not drink water today'

\section{Nominal and pronominal objects}

I would like to react now against a tendency to treat the position of pronominal objects on a par with the position of object NPs in constituent order studies concerning the Niger-Congo family. This confusion leads in particular to a drastic overestimation of the importance of the Mande type of constituent order. In the languages of the world, weak object pronouns prefixed to verbs are extremely common in otherwise robust $S-V-O$ languages. Therefore, there is nothing particularly strange in the fact that so many Niger-Congo languages are strict $S$ - $V-O$ languages as regards the ordering of NPs, but have weak object pronouns prefixed to verbs. In other words, it is contradictory to present the Mande type of word order as an exotic constituent order pattern, virtually non-existent outside Africa, and to use at the same time data from languages in which pronominal objects only precede the verb to demonstrate the alleged pervasiveness of this type of constituent order among Niger-Congo languages.

This has important consequences concerning the use of typological data in reconstruction, since proposals to reconstruct a constituent order with the object before the verb (either canonical $S-O-V$, or a pattern of the Mande type) in ProtoNiger-Congo crucially rely on the assumption that, when pronominal objects do not occur in the same position as object NPs, the position of pronominal objects can be assumed to reflect the position of object NPs in an ancient state of the language.

In languages with a flexible constituent order, the default position of pronominal objects may be different from that of object NPs, due to their high degree of inherent topicality. For example, in Russian, a language with a particularly flexible constituent order, the less marked order is very clearly $S$ - $V$ - $O$ with object NPs, but rather $S-O-V$ with personal pronouns in the role of object.

Morevover, pronouns tend to cliticize, and it is well known that prosodic 
factors independent from constituent order typology are crucial for the evolutions in the positioning of clitics. For example, second position clitics are not restricted to languages having a particular pattern of constituent order. Consequently, nothing ensures that the position occupied by object clitics or affixes at some stage in the evolution of a language should reflect the position occupied by object NPs at a more ancient stage. The well-known and often-quoted slogan 'Today's morphology is yesterday's syntax' certainly does not hold for pronominal affixes.

For example, in modern Romance languages, object NPs invariably follow the verb, but in most of them (Portuguese being the main exception), weak object pronouns invariably attach to the left of finite verb forms. In French, this rule of left-attachement extends to non-finite verb forms, and the imperative positive is the only exception. Following an argumentation of the type developped in attempts to reconstruct the constituent order of Proto-Niger-Congo that take the position of object clitics or affixes as an evidence of the position previously occupied by object NPs, a constituent order of the Mande type should be reconstructed in Proto-Romance, which is certainly not correct. Latin had a flexible constituent order with the verb in final position as the less marked option, and modern Romance languages have more or less flexible patterns of constituent order with a clear predominance of $S-V-O-X$, but there is no evidence that $S-O-V-X$ played a role as an intermediate stage in the shift from the Latin pattern of constituent order to that of modern Romance languages. Moreover, the history of Romance languages is well documented enough to establish that the position of pronominal objects in modern Romance languages results from evolutions that cannot be characterized as the maintenance of the position occupied by object NPs at some stage in the history of Romance languages.

\section{Conclusion.}

In the attempts to reconstruct the history of constituent order patterns in the West African language families belonging to the Niger-Congo phylum, the only hypothesis relying on a firm empirical basis is that Proto-Mande already had a constituent pattern of the type attested by modern Mande languages. By contrast, the historical interpretation of the similarities and differences between the Mande constituent order pattern and the alternating constituent order patterns found in other West African languages families is far from clear.

In my opinion, most studies dealing with this question have greatly underestimated the differences between the Mande constituent order pattern and the alternating patterns found in Kwa, Gur, Kru, and Atlantic languages. In section 4 , I have tried to show that the differences are of two types that, from a historical point of view, seem to point in opposite directions:

-on the one hand, the absolute rigidity of the position of the object in the Mande pattern suggests a Mande influence in the diffusion or maintenance of constituent order patterns in which the object can be inserted between the subject and the verb; 
-on the other hand, in West African languages with alternating constituent order patterns, the range of nominal terms that can be inserted between the object and the verb is considerably wider than in Mande languages, which leads to reject the hypothesis of an areal diffusion from Mande languages, and casts serious doubts on the reconstruction of a constituent order pattern of the Mande type in Proto-Niger-Congo too, since it is difficult to explain why so many West African languages would have at the same time shifted to $S-V-O$ in certain conditions, and widened the range of nominal terms inserted between the subject and the verb in other conditions.

I have no solution to propose to this puzzle, but it think it is important to emphasize that a fine-grained typology of constituent order patterns in West Africa does not confirm the current view according to which, in languages with alternant constituent order patterns, the variant with the object between the subject and the verb can be identified with the Mande type of constituent order.

\section{Abbreviations}

$\mathrm{APPL}=$ applicative, CAUS $=$ causative, $\mathrm{DAT}=$ dative, $\mathrm{DEF}=$ definite, $\mathrm{DEM}=$ demonstrative, $\mathrm{P}(\mathrm{L})=$ plural, $\mathrm{PM}=$ predicative marker, $\mathrm{Po}=$ postposition, $\mathrm{Pr}=$ preposition, $\mathrm{S}=$ singular, TAM = tense-aspect-modality marker

\section{References}

Bearth, T. 1995. Nominal periphrasis and the origin of the predicative marker in Mande languages - an alternative view. Afrikanistische Arbeitspapiere 41:89117.

Bird, C. \& M. Rendall. 1986. Postpositions and auxiliaries in Northern Mande: Syntactic indeterminacy and linguistic analysis. Anthropological Linguistics 28-4:389-403.

Carlson, R. 1991. Grammaticalization of postpositions and word order in Senufo languages. In Traugott E. C. \& B. Heine (eds.), Approaches to grammaticalization. Vol. 2:201-223. Amsterdam / Philadelphia: Benjamins.

Carlson, R. 1994. A grammar of Supyire. Berlin: Mouton de Gruyter.

Childs, T. 1995. A grammar of Kisi. Berlin: Mouton de Gruyter.

Childs, T. 2003. It's everywhere! More on the S-Aux-O-V-Other in Atlantic. Paper presented at CALL 33. University of Leiden.

Claudi, U. 1994. Word order change as category change: the Mande case. in Pagliuca, W. \& Davis, G. (ed.) Perspectives on grammaticalization. Amsterdam: Benjamins, 201-241.

Creissels, D. 1997a. Postpositions as a possible origin of certain predicative markers in Mande. Afrikanistische Arbeitspapiere 50,5-17. 
Creissels, D. 1997b. Une tentative d'explication de particularités tyologiques de la négation en mandingue. Mandenkan 32,3-22.

Gensler, O. 1994. On reconstructing the syntagm S-Aux-O-V-Other to ProtoNiger-Congo. In Moore, K. E., D. A. Peterson \& C. Wentum (eds.), Proceedings of the Twentieth Annual Meeting of the Berkeley Linguistic Society, February 18-21, Special Session on Historical Issues in African Linguistics, 1-20. University of California, Berkeley.

Gensler, O. 1997. Grammaticalization, typology, and Niger-Congo word order: Progress on a still-unsolved problem. Journal of African Languages and Linguistics 18-1:57-93.

Gensler, O. \& T. Güldemann. 2003. S-Aux-O-V-Other in Africa: Typological and areal perspective. Paper presented at WOCAL 4. New Brunswick, NJ: Rutgers University.

Grah, C. 1983. Approche systématique du níw̄̄̄I. University of Paris.

Heath, J. 1999.A grammar of Koyraboro (Koroboro) Senni. Köln: Rüdiger Köppe.

Heine, B. 1976, A typology of African languages, based on the order of meaningful elements, Berlin: Reimer.

Heine, B. \& M. Reh. 1984. Grammaticalization and reanalysis in African languages. Hamburg: Helmut Buske.

Kastenholz, R. 2003. Auxiliaries, grammaticalization, and word order in Mande. Journal of African Languages and Linguistics 24-1:31-53.

Kouadio, N. J. 1996. Description systématique de l'attié de Memni. Thèse de doctorat d'état. University of Grenoble.

Lord, C. 1993. Historical change in serial verb constructions. Amsterdam / Philadelphia: Benjamins.

Oumarou Yaro, B. 1993. Eléments de description du zarma. PhD thesis. University of Grenoble.

Denis Creissels

DDL - ISH

14, avenue Berthelot

69363 Lyon cedex07

France

denis.creissels@univ-lyon2.fr 